\title{
Model of chip formation during turning in the presence of a built-up edge (BUE)
}

\section{Zoltán Pálmai}

University of Miskolc, Department of Production Engineering, Hungary.palmayz@t-online.hu

During turning, in the course of the deformation of the material, a metallic deposit, a so-called built-up edge (BUE), may occasionally form, which may damage the surface and shorten the tool life. We have observed the effect thereof on chip formation using microscopic techniques and have developed a mathematical model for this process. Laboratory experience confirms the numeric solution of the time-delayed autonomous differential equations. This model can be applied to other technologies as well where the thickness of the undeformed chip varies.

Keywords: cutting, chip formation, mathematical model, built-up edge (BUE)

\section{Acknowledgements}

I would like to express my gratitude to my colleague Gábor Csernák for his help with the MathLab applications and my colleague József Pap who conducted the measurements of cutting force.

The described work was carried out as part the TAMOP-4.2.1.B-10/2/KONV-2010-0001 project in the framework of the New Hungarian Development Plan. The realisation of this project is supported by the European Union, cofinanced by the European Social Fund.

\section{References}

[1] RAPATZ, F., Das Oberflächenaussechen bei der Spanabhebenden Bearbeitung Insbesondere beim Drehen, Archiv für das Eisenhüttenwesen, Vol. 3. 1929-1930. pp.717.

[2] PEKElHARING, A.J., Buit-Up Edge (BUE): Is the Mechanism Understand? Annals of the CIRP. Vol. 23/2 (1974) pp. 207-212.

[3] FANG, N., P. Dewhurst, Slip-line modelling of built-of edge formation in machining. Int Journ Mechanical Sciences 47 (2005) pp. 1079-1098.

[4] KLOCKE, F., Manufacturing Processe 1 Cutting, Springer, Aachen 2011.pp. 77.

[5] PÁLMAI Z., Erhöhung der Standzeiten von Schnellarbeitsstahl-Schneidwerkzeugen durch Anwendung belagbildender Stähle. Archiv für das Eisenhüttenwesen, 55 (1984) No. 4. pp.177-180.

[6] PÁLMAI, Z., A method for the approximate determination of the specific material properties of metals under the extreme conditions of fast deformation. Materials Science Forum Vol. 659 (2010) pp.79-84.

[7] PÁLMAI Z., G. CSERNÁK, Chip formation as an oscillator during the turning process. Journ. of Sound and Vibration 326 (2009) pp. 809-820.

[8] PÁLMAI Z., G. CSERNÁK, The thermomechanical model of built-up-edge formation during turning. VII. Conference on Mechanical Engineering, Budapest May 25-26. 2010.

[9] SHTEINBERG, J.S., Ustranenie vibratsi, voznikayushchikh pri rezanii metallov na tokarnom. USSR, Mashgiz, 1947.

[10] SUCHÁNEK DAVID, DUŠAK KAREL, Impact of cutting conditions on tool wear. Strojirenská technologie XVI. 2011. 5. 33-37.

[11] KAROL VASILKO, Physical and Metallurgical Approaches to Chip Creation. Manufacturing Technology 2006. VI. December 06. 56-62.

[12] BOHUMIL BUMBÁLEK, LEOŠ BUMBÁLEK, Model of Shear Instability During Cutting. Manufacturing Technology 2002. III. June 37-42.

[13] ARRASOLA, P.J., O. BARBERO, I. URRESTI, Influence of Material Parameters on serrated chip prediction in finite element modelling of chip formation process. Int. Journ. Mater. Form. (2010) Vol. 3. Suppl. 1:519-522.

[14] PITTALÁ, G.M., M. MONNO, Flow stress determination in orthogonal cutting process comrbining the primary and the secondary shear zones. Int. Journ. Mater Form. (2010) Vol. 3. Suppl. 1:483-486.

[15] R. RUSINEK, Cutting process of composite materials: An experimental study. Int. Journ. of Non-Linear Mechanics 45 (2010) 458-462. 
[16] DAVIM, J.P., C. MARANHÃO, A study of plastic strain and plastic strain eate in machinig of steel AISI 1045 using FEM analysis. Materials and Desing 30 (2009) 160-165.

[17] JIANG, M.Q., L.H. Dai, Formation mechanism of lamellar chips during machinig of bulk metallic glass. Acta Materialia 57 (2009) 2730-2738.

[18] LITAK, G., A. SYTA, M. Wiercigroch, Identification of chaos in a cutting process by the 0-1 test. Chaos, Solitons and Fractals 40 (2009) 2095-2101.

[19] LITAK, G., ASOK K. SEN, A. SYTA, Intermittent and chaotic vibration in a regenerative cutting process. Chaos, Solitons and Fractals 41 (2009) 2115-2122.

[20] OVERCASH, J.L., J. F. Cuttino, In-process modelling of dynamic tool-tip temperatures of a turning device operating at ultrasonic frequencies. Precision Engineering 33 (2009) 505-515.

[21] COTTERELL, M., G. BYRNE, Dynamics of chip formation during orthogonal cutting of titanium alloy Ti-6Al4V. CIRP Annals - Manufacturing Technology, 57 (2008) Iss. 93-96.

[22] PALMAI, Z. Chaotic Phenomena Induced by the Fast Plastic Deformation of Metals During Cutting. Trans. ASME - Journal of Applied Mechanics, March 2006. Vol. 73. 240-245.

[23] WANG, X.S., J. HU, J.B. GAO, Nonlinear dynamics of regenerative cutting processes - Comparison of two models. Chaos, Solitons and Fractals 29 (2006) 1219-1228.

Paper number: M201243

Manuscript of the paper received in 2012-10-08. The reviewers of this paper: Stanislaw Legutko, Karel Kocman. 